but, as proved by the French coast-beds with sea-shells, there was an episode of subsidence, as in England, as proved by the Sussex raised-beach, the Burtle-beds of Somersetshire, and the Shirdley Hill Sand of Lancashire; at the same time rivers higber up on the land were depositing the massive gravels, and in Cornwall the tin-stone beds found beneath the peat. After the obstruction of drainage caused by elevation, that produced the peat, gave way, the country subsided a little, and the relative levels of land and sea have remained tolerably constant since the Roman era.

\title{
VISIT TO THE MINERALOGICAL DEPARTMENT OF THE MUSEUM OF PRACTICAL GEOLOGY.
}

$$
\text { MaRCh 22ND, } 1875 .
$$

Director-F. W. Rudler, Esq., F.G.S., Dir.A.I.

$$
\text { (Report by Mr. Rudler.) }
$$

Before commencing the inspection of the Mineral Collection, the Director explained the principal systems which have at various times been proposed for the classification of minerals. He contrasted the natural-history method of Mohs and his school with the chemical methods of Berzelius and his followers, and remarked that after Berzelius had founded a system in which the electropositive element formed the leading characteristic, be was led, by Mitscherlich's discovery of isomorphism, to construct a new system in which the electro-negative element was the basis of classification. It was argued that a purely chemical and crystallographic arrangement, though of great value scientifically, scarcely satisfied the requirements of the geological student and the practical miner; and the mixed system followed in the Museum of Practical Geology was defended as the most useful for such purposes. The minerals containing the heavy metals are arranged in the wall-cases, all the ores of a given metal being grouped together; whilst the minerals which are destitute of metal, or contain only the lighter metals, are placed in the so-called Horseshoe Case. It was to these "non-metallic" minerals that the attention of the visitors was restricted, special notice being taken of such species as are important as rock-constituents. After the elementary substances carbon and sulphur, had been described, at- 
tention was called to those minerals which contain alkaline metals, such as rock salt. The few minerals containing barium and strontium led to the salts of calcium, which include such important species as calcite, gypsum, fluor-spar, and apatite. These were succeeded by a large series illustrating the various forms of silica, and these in turn by a small collection of the varieties of alumina. Then followed the great group of silicates, both hydrous and anhydrous; the latter including some of the most important species to the petrologist, such as the felspars, micas, hornblendes, and augites.

\section{EXCURSION TO THE ISLE OF THANET.-EAster Monday, March $29 \mathrm{TH}, 1875$, and following day.}

Director-Geonat Dowken, E\&Q., F.G.S.

\section{(Report by Wilfrid H. Hunleston, Esq., M.A., F.G.S.)}

The party quitted the Railway Station, at Ramsgate, shortly after 1 p.m. on Easter Monday, and proceeded at once towards Pegwell Bay. Arrived on the shore, Mr. Dowker began the work of the day by pointing out, in the first place, an irregular mass of gravel and brick-earth, generally believed to be of fluviatile origin. It rests, in this place, directly upon the Chalk, and is considered to be of the same age as certain high level gravels resting on the Lower Tertiaries near Herne Bay, in which palæolithic implements have been found. Some geologists have referred its deposition to the Mid-Glacial period, but there seems to be much-doubt as to this. A member of the party had recently found both Buccinum, and Ostrea in the deposit, hut whether these got in from above or are really a part of the deposit there is at present no evidence to show.

The Isle of Thanet is a somewhat oval mass, of moderately high ground, separated from the mainland of Kent by a belt of marsh, which though now banked in and drained, has within the historical period been a shallow strait into which the estuary of the river Stour discharged, and which communicated freely with the sea, on the north, at Reculvers (Regulbium), on the south east near Richborough (Rutupia). The constituent rock of the Isle is Chalk, which rises in a sort of gentle anticlinal swelling, having an axis with a mean direction, E.N.E.-W.S.W. It falls away also to the westward, whilst on the east its section by the sea 